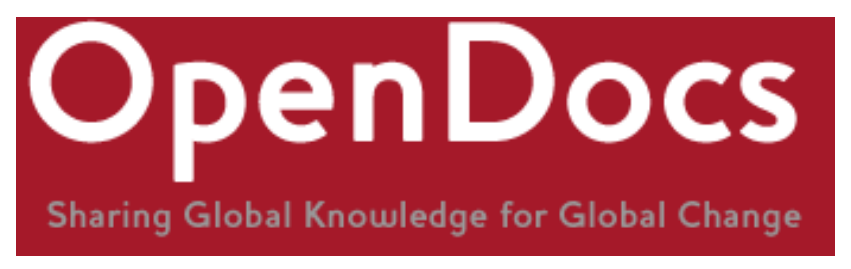

Title: A Life Cycle Assessment (LCA) of Greenhouse Gas Emissions from SRI and Flooded Rice Production in SE India.

Citation: Gathorne-Hardy, A. (2013) A Life Cycle Assessment (LCA) of Greenhouse Gas Emissions from SRI and Flooded Rice Production in SE India, Taiwan Water Conservancy Journal 61 (4), pp. 111-125.

Official URL: http://140.112.63.162/pdf/61/61-4-110-125.pdf

More details/abstract: Rice feeds more people than any other crop, but each kilogram of rice is responsible for substantially more greenhouse gas (GHG) emissions than other key staple foods. The System of Rice Intensification (SRI) has recently received considerable attention for its ability to increase yields while using less water. Yet so far there has been little research into the GHG emissions associated with SRI production systems, and how they compare to those from conventional flooded-rice production techniques. A streamlined Life Cycle Assessment (LCA) methodology was used to compare the GHG emissions and groundwater use from SRI and from conventional rice production. Input data were derived from farmer questionnaires in SE India and appropriate secondary data sources. The results showed that SRI methods substantially raised farmers' yields, from 4.8 tons to 7.6 ton per hectare, a $58 \%$ increase, while reducing water applications. At the same time it was seen that SRI management offered opportunities for significant GHG reductions, both per hectare and per kilogram of rice produced. These savings principally arise from reduced methane emissions and reduced embodied emissions in the electricity used to pump water for irrigation. SRI nitrous oxide emissions were somewhat higher than on control farms, but the difference was significant only per hectare, not per $\mathrm{kg}$ of rice. The net effects of SRI practice on reducing global warming potential were positive in that the small increases in N2O did not offset the larger diminishment of $\mathrm{CH} 4$.

Version: Accepted version.

Terms of use: This document is the author's final accepted version of the journal article. There may be differences between this version and the published version. You are advised to consult the publisher's version if you wish to cite from it: http://140.112.63.162/pdf/61/61-4110-125.pdf

This is a download from OpenDocs at the Institute of Development Studies

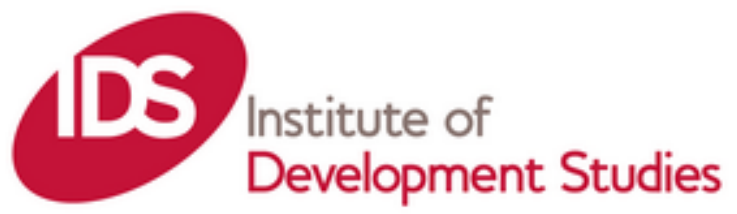




\title{
A Life Cycle Assessment (LCA) of Greenhouse Gas Emissions from SRI and Flooded Rice Production in SE India
}

\author{
Alfred Gathorne-Hardy ${ }^{1 *}$, with D. Narasimha Reddy ${ }^{2}$, Motkuri \\ Venkatanarayana $^{2}$ and Barbara Harriss-White ${ }^{1}$ \\ ${ }^{1}$ Oxford University, Oxford, UK; ${ }^{2}$ National Institute for Rural Development, \\ Hyderabad, India*Corresponding author: alfred.gathorne-hardy@ area.ox.ac.uk
}

\begin{abstract}
Rice feeds more people than any other crop, but each kilogram of rice is responsible for substantially more greenhouse gas (GHG) emissions than other key staple foods. The System of Rice Intensification (SRI) has recently received considerable attention for its ability to increase yields while using less water. Yet so far there has been little research into the GHG emissions associated with SRI production systems, and how they compare to those from conventional flooded-rice production techniques.

A streamlined Life Cycle Assessment (LCA) methodology was used to compare the GHG emissions and groundwater use from SRI and from conventional rice production. Input data were derived from farmer questionnaires in SE India and appropriate secondary data sources.

The results showed that SRI methods substantially raised farmers' yields, from 4.8 tons to 7.6 ton per hectare, a 58\% increase, while reducing water applications. At the same time it was seen that SRI management offered opportunities for significant GHG reductions, both per hectare and per kilogram of rice produced. These savings principally arise from reduced methane emissions and reduced embodied emissions in the electricity used to pump water for irrigation. SRI nitrous oxide emissions were somewhat higher than on control farms, but the difference was significant only per hectare, not per $\mathrm{kg}$ of rice. The net effects of SRI practice on reducing global warming potential were positive in that the small increases in $\mathrm{N}_{2} \mathrm{O}$ did not offset the larger diminishment of $\mathrm{CH}_{4}$.
\end{abstract}

Key words: flooded rice production; greenhouse gas emissions; Life Cycle Assessment; System of Rice Intensification

\subsection{INTRODUCTION}

Rice is the most important staple crop worldwide, directly feeding more than half the world's population. However, rice is also the most greenhouse gas-intensive staple crop, producing about four times more GHG emissions per ton than wheat or maize (Linquist et al. 2012). The System of Rice Intensification (SRI) is novel set of rice production techniques that has recently received considerable attention for their ability to increase yields. This paper 
uses a streamlined Life Cycle Assessment (LCA) methodology (White 2010) to compare the GHG emissions and groundwater use resulting from conventional and SRI rice production systems.

Three GHGs are important from rice production: carbon dioxide $\left(\mathrm{CO}_{2}\right)$, methane $\left(\mathrm{CH}_{4}\right)$ and nitrous oxide $\left(\mathrm{N}_{2} \mathrm{O}\right)$. GHG emissions from conventional rice production are largely associated with its water use via two mechanisms; first, through the embodied emissions associated with irrigation provision, and second, from flooded soils which create the anaerobic soil environments that drive microbial methane production. While rice does not need to grow in flooded conditions, most rice does come from ponded systems (IRRI 2013). This production system uses an estimated $34-43 \%$ of global irrigated water, or $24-30 \%$ of the total freshwater withdrawals (Bouman et al. 2007). The pattern of GHG emissions from nonflooded rice can be very different, with nitrous oxide playing an important role.

Embodied irrigation emissions derive from the energy used for pumping water. In gravity-fed irrigation systems, this energy requirement can be minimal; but it can be high with diesel-based groundwater extraction systems, or when using electricity not generated by hydropower (Nelson et al. 2009).

The net methane emission from any specific paddy field is determined by a wide range of factors (Adhya et al. 2000; Gathorne-Hardy 2013a; Yan et al. 2005), but two main drivers dominate methane production: irrigation patterns, and the quantity of organic material in the soil. The rate of oxygen diffusion through water is 10,000 times slower than through air, so irrigation with flooding/ponding produces anaerobic conditions within hours of flooding (Adhya et al. 2000; Bodelier 2003; Chanton et al. 1997).

Under anaerobic soil conditions, methanogens (methane-producing bacteria) produce methane as a by-product of their respiration of organic matter. Under such conditions, the supply of substrates for methanogens' subsistence is the commonest limiting factor (Wang et 
al. 2000; Yao et al. 1999). Organic matter in paddy fields originates from both direct byproducts of rice production (such as sloughed-off root cells and root exudates) and from added materials (manures and crop residues). Control of methanogens' substrates is only possible from modifying the latter.

In most arable agriculture, $\mathrm{N}_{2} \mathrm{O}$ is the dominant $\mathrm{GHG}$, for example responsible for $80 \%$ of wheat GHG emissions (Woods et al. 2008). Nitrous oxide is naturally produced from soils during nitrification and de-nitrification by bacteria. In India, $\mathrm{N}_{2} \mathrm{O}$ is estimated to be responsible for $13 \%$ of agricultural GHG emissions (MEF 2010).

However, direct $\mathrm{N}_{2} \mathrm{O}$ emissions from flooded paddy fields are minimal, as nitrification does not occur under anaerobic conditions. Consequently neither can de-nitrification occur, due to lack of $\mathrm{NO}_{3}{ }^{-}$in the soil (Qin et al. 2010). Even though minimal $\mathrm{N}_{2} \mathrm{O}$ emissions are likely from the flooded soils, still some off-site (indirect) $\mathrm{N}_{2} \mathrm{O}$ emissions are likely from irrigated rice production due to the addition of nitrogen fertiliser to fields because nitrogen compounds can leach through the soil or are directly drained from the site.

The frequent draining of SRI-managed paddies creates intermittently aerobic soil conditions that will allow bacterial nitrogen cycling in the soil, which can potentially increase the $\mathrm{N}_{2} \mathrm{O}$ emissions from SRI fields compared to flooded fields (Hansen et al. 1993; Yan et al. 2000; Zheng et al. 2000). A trade-off is therefore expected between methane and nitrous oxide as fully anaerobic soils inhibit the generation of $\mathrm{N}_{2} \mathrm{O}$ while facilitating methane emissions. A more complicated relationship between $\mathrm{CH}_{4}$ and $\mathrm{N}_{2} \mathrm{O}$ emissions with regard to flooded paddy fields is reported in this issue, however, when soil temperature, $\mathrm{pH}$ and other factors are taken into account (Setiawan et al.). Also, several unpublished studies of this relationship have not found $\mathrm{N}_{2} \mathrm{O}$ increases offsetting $\mathrm{NH}_{4}$ reductions under SRI management. So this is a subject warranting further detailed investigation. 


\subsection{The System of Rice Intensification}

SRI methodology, developed in Madagascar in the 1980s, involves certain basic practices that differ from age-old production techniques: (a) earlier transplanting, at the 2-3 leaf stage, typically less than 15 days old, compared to up to 30-45 days old for conventional rice transplanting; (b) only one plant per hill, in contrast to 3-5 or more plants; (c) hills laid out in a grid pattern with wide spacing; (d) increased use of manure and other organic fertilisers; and (e) intermittent flooding and draining of the rice paddies rather than continuously flooded soils (Reddy and Mortkori 2013; Stoop et al. 2002; Uphoff 2008). Controlling weeds by the use of a mechanical implement which disturbs the soil surface is highly recommended to achieve the active soil aeration that better supports the growth of roots and the aerobic soil biota.

While there has been controversy in the literature about the range of benefits associated with SRI (Sumberg et al. 2013), a wide range of scientific journal articles, NGO literature, and anecdotal reports suggest that grain yield gains are usually associated with it, as well as reduced water use (Kassam et al. 2011; Sinha and Talati 2007; Uphoff 2008; WWF 2007). However, there has been very little measurement of GHG emissions from SRI fields compared to conventional paddy production. The literature offers little evidence that can used to assess reliably the relative GHG impact of SRI crop and water management compared to conventional production techniques (Choi et al. 2013).

Without systematic and quantified evidence it is hard to predict what the GHG impact is likely to be since SRI management has direct impacts on many of the key paddy GHG production processes. Methane emissions may be increased due to increased organic soil amendments, or they could be decreased due to increased soil aeration. Nitrous oxide $\left(\mathrm{N}_{2} \mathrm{O}\right)$ emissions, usually minimal from anaerobic (flooded) paddy fields, may increase when soils are made more aerobic under SRI practice; or they could be little changed if the $\mathrm{N}$ supplied to 
fields is in organic rather than inorganic forms, so there is little excess reactive $\mathrm{N}$ to be converted by microbial activity. Repeated flooding and drainage should result in less water use; but whether pumping is actually reduced will depend upon the actual amount of flooding and drainage compared to traditional water use, as well as on the kind and amount of energy used for irrigation.

\subsection{Life Cycle Assessment}

The research reported here modelled and evaluated $\mathrm{GHG}\left(\mathrm{CO}_{2}, \mathrm{CH}_{4}\right.$ and $\left.\mathrm{N}_{2} \mathrm{O}\right)$ emissions from SRI compared to conventional flooded-irrigation paddy production techniques up to the farm gate. Data were collected from Andhra Pradesh, India. It is part of a larger project that generates and utilizes primary data to understand how a range of environmental effects (GHG emissions, fossil and non-fossil energy, groundwater), social considerations (e.g., the qualities, quantities and gender of jobs), and economic factors (costs, returns, value-added) interact along the entire rice production-distribution supply chain, from field to shop, for four different rice production techniques (SRI, organic, rainfed, and current conventional management) and four different retail outlets. More information can be found at http://www.southasia.ox.ac.uk/research-resources-potential-new-applications-resources-greenhouse-gasestechnology-and-jobs-indias.

GHG emissions from rice production were quantified using an analytical tool called Life Cycle Assessment (LCA). LCA is defined as the "compilation and evaluation of the inputs, outputs and the potential environmental impacts of a product system throughout its life cycle' (ISO 2006). This includes all stages required for the creation of the material of interest through to its disposal or recycling, and it includes a variety of criteria that range from energy use to eco-toxicity. The research detailed in this paper is limited to assessing GHG emissions and groundwater use, not the wider range of environmental impacts included within a fully LCA, so accordingly we refer to the analysis as 'streamlined' LCA (White 2010). 


\subsubsection{Issues of allocation}

When more than one output is produced from a process, the associated emissions must be allocated between or among them (European Commission, 2010; ISO, 2006). Consider, for example, the role of livestock in paddy production. In addition to providing manure for maintaining soil fertility, and in some cases providing traction (ploughing), cows produce calves and milk. All of these outputs may have economic value. To assign all the emissions from cows to just one of these outputs would give one output an inflated debit and would give the other outputs unwarranted credit in terms of their respective contributions to global warming potential (GWP).

Accordingly, the overall emissions from a production process must be allocated appropriately between or among the outputs. Allocation can occur through different measures, including by mass, by energy content, or by value (Anon. 2009). Economicallybased allocation of emission 'debits' best reflects the drivers of production (Williams et al. 2006). In economic allocation, the proportional allocation of emissions to each co-product is determined by the respective economic value of each co-product, on the assumption that the co-products drive the total production in proportion to their economic value.

The paddy field itself is a multi-functional resource, producing straw as well as paddy. Yet in rice LCAs, rice straw is commonly not allocated to the emissions attributed to rice (Blengini and Busto 2009), or even more commonly it is not even mentioned (Blengini and Busto 2009; Hokazono and Hayashi 2012; Wang et al. 2010). As a useful by-product (straw can be used for animal bedding, as soil mulch cover, for fodder or cooking, and in some parts of India for paper making), it should be allocated a share of the environmental burden associated with rice production. 
Since approximately equal weight and energy are involved in the production of straw and paddy grain, the environmental costs/benefits of straw and paddy should be allocated equally if mass or energy is used as the criterion of allocation. But this would not reflect the motivating factors for paddy farming, which is driven mostly by paddy production expectations, with straw considered by producers as a potentially useful by-product. This makes economically-based allocation more realistic. Economic methods to allocate emissions to straw are discussed under Methods, below.

\subsection{METHODS}

This research modelled GHG emissions from SRI and conventional/intensive rice production techniques (the latter hereon referred to as 'control') from a case study site in Andhra Pradesh, India. Life Cycle Assessment (LCA) was used to determine the GHG emissions based on the standards and criteria of ISO 14040, PAS 2050, and the ILCD handbook (European Commission 2010; ISO 2006; BSI 2011). A mixture of primary and secondary data was involved to construct the quantified analysis.

Primary data on farmers' practises and results were collected in the second half of 2012 for the crops of the preceding agricultural year (2011-2012). Data were collected using recall methods via an extensive (31-page) survey of selected farm households. These data were collected as part of a wider project, looking at how social, economic and environmental criteria all interact within the rice production and supply chain. Secondary data included inventory data from a range of sources, as detailed in the Annex.

Data collection took place in the Janagaon region of Warangal District, Andhra Pradesh, SE India. This is a semi-arid area with average annual rainfall of $865 \mathrm{~mm}$, concentrated in the SW monsoon season, with $624 \mathrm{~mm}$ falling from June to September (Anon. 2013). The altitude is approximately $380 \mathrm{~m}$ above sea level. 
Twenty 'SRI' farms were sampled along with 10 control farms in the area. While this sample size is not large, due to the logistical limitations associated with the extensive data collection required for the wider project as discussed in section 1.2 above, the results reviewed in section 3.0 passed a number of statistical tests and are unlikely to be due to chance. The control farms were ones using standard, intensive, flooded paddy production and 'Green Revolution' production methods. The key agronomic practices used in the two sets of farmers are reviewed in sections 3.1 and 3.2 below.

The farms using SRI methods in our sample were not necessarily using the full set of SRI practices or using them all as recommended, but there were demonstrable and significant differences between the sets of practices being evaluated. Possibly the differences in results reported here would have been greater or different if the evaluation of SRI methods had been done more strictly, under strictly controlled conditions. But for this study, we wanted to consider the results of actual practice, which is invariably imperfect. In philosophical terms, what was evaluated was the 'existence' of SRI rather than its 'essence.'

Individual farms for both control and SRI surveys were chosen using a semi-random snowballing technique, the semi-random aspect including selection of farms aimed to ensure that the distribution of farms sizes was representative of that in the area as reported in the Agricultural Census. There proved to be no statistical difference between control and SRI farms in key socio-economic and environmental attributes (farm size and water table), as seen in section 3.2. Climate variables were not considered due to the close and overlapping locations of the control and SRI farms.

\subsection{Functional units}


This paper uses two approaches to understand the GHG impacts of SRI production techniques - a bottom-up, land-based approach, and a top-down, product-based approach. Bottom-up approaches are useful for measuring those environmental impacts that are most relevant (directly or indirectly) on an area basis - for example, groundwater use, electricity use, as well as impacts not measured in this study (water pollution, local air pollution, etc.). Bottom-up, area-based measures are also the metrics most commonly used by farmers. However, consumers do not buy areas of land; they buy the produce from the land. From their perspective, environmental impact per unit of product (paddy rice) is a relevant metric.

Two functional units for analysis are thus used to reflect these bottom-up and top-down approaches to evaluating rice production, respectively:
a. $\quad 1$ hectare for one season of paddy production (area-based)
b. $\quad 1 \mathrm{~kg}$ of paddy at the farm gate (product-based).

\subsection{System baselines and boundaries}

Establishing an appropriate baseline (counter-factual) and boundaries is critical for accurate, meaningful and representative results (Gathorne-Hardy 2013b). In this study, the baseline to which SRI practices are compared is the Green Revolution paddy-farming system by which most rice is produced in India today.

The boundaries included all inputs and processes necessary to grow paddy that make a material difference to the final figures. We used $1 \%$ of the total as our criterion for a material difference and did not consider any effect that was less than this. In this paper, inputs to postharvest processes that convert paddy into processed, polished rice were not included. These are covered elsewhere (Gathorne-Hardy and Harriss-White 2013).

The boundaries to this study are shown in Error! Reference source not found.Error! Reference source not found.. The central black box shows the processes for which we 
collected data. Everything within the blue box is included in the study. Outside this box are four key elements that have not been included in the research reported here.

[Figure 1 about here]

Embodied water (the water used off-site for the production of goods/energy, for example, tractors or electricity) was not included in the analysis due to lack of available data. Neither was surface water included due to lack of ability to capture such data accurately using recall surveys. However, this source of water contributes practically nothing to GWP, and no farms in the sample irrigated with any other sources of water except groundwater and precipitation.

Embodied emissions associated with buildings were also not included because paddy is normally stored - if stored at all - in the producer's dwelling, and no other buildings were deemed relevant to the production system for the field conditions observed. The main items of machinery such as tractors and power tillers were included. Early analysis showed that the combined embodied GHG emissions for other implements (weeders, trailers, levelling plates, and ploughs) fell well below $1 \%$ inclusion criterion for material difference, so these were not included in the analysis.

Allocation between co-products has been based on economic methods in this study. Allocation to straw is made more difficult within this study for three reasons: (i) there is rarely a market for the straw, (ii) few farmers know how much straw they harvest, and (iii) straw that leaves the field sometimes, although not always, is returned to the field as manure. The methods and measures that we have used to allocate GHG emissions to straw are detailed in the next section. 


\subsection{Inventory analysis and data sources}

This section explains what information was collected, and what conversion factors were used to generate the LCA model. This model aims to account for the amounts and sources of GHG emissions that drive up global warming potentials, discussed below in some detail.

\subsubsection{Assessment of global warming potentials}

To calculate GHG equivalents, we used 100 -year global warming potentials $\left(\mathrm{GWP}_{100}\right)$ as specified by IPCC 2007 (Forster et al. 2007). GWP is a measure of how much heat is retained in the atmosphere for each gas, and the 100 indicates that the figures have been averaged to assess the heat retained over a period of 100 years. GWPs are set up in reference to carbon dioxide $\left(\mathrm{CO}_{2}\right)$, which is given a value of 1 .

The three main agricultural GHGs of concern are carbon dioxide $\left(\mathrm{CO}_{2}\right)$, methane $\left(\mathrm{CH}_{4}\right)$, and nitrous oxide $\left(\mathrm{N}_{2} \mathrm{O}\right)$, which have GWPs, respectively, of 1, 25 and 298, meaning that over 100 years, $1 \mathrm{~kg}$ of $\mathrm{N}_{2} \mathrm{O}$ released to the atmosphere will retain 298 times the amount of heat retained by $1 \mathrm{~kg}$ of $\mathrm{CO}_{2}$ in the atmosphere. Using this metric, $1 \mathrm{~kg}$ of $\mathrm{CO}_{2}$ is 25 times less carbon-polluting than releasing $1 \mathrm{~kg}$ of $\mathrm{CH}_{4}$. Levels of $\mathrm{CH}_{4}$ and $\mathrm{N}_{2} \mathrm{O}$ emissions for flooded control irrigation paddy farm systems were taken directly from IPCC (2006). Emissions for SRI rice production systems are not included in the IPCC report, so measured emissions from controlled irrigation trials were used as a proxy, as described in the Annex. The data sources and assumptions or coefficients used in calculation are given in the Annex.

\subsubsection{Inputs not covered in the analysis}

Jeevamirtham, a solution of water, manure, cattle urine, jaggery and various other products, is used by organic and non-organic farmers as a fertiliser and pesticide. Typically it is mixed and retained in a barrel for a few days before it is applied to the crop, often with the 
incoming water. The nutrient content of its ingredients is not substantial, but this mixture has been reported to provide additional $\mathrm{N}$ for the soil and crop via $\mathrm{N}$-fixing bacteria. This input has not been included, but is not large.

Azospirillum, phosphobacteria, Pseudomonas, Azolla, and other microbial/biological products used with SRI production have not been assigned embodied emissions in this analysis. There are no data on which to base any assumptions about GHG emissions, and when the authors inspected the facilities where they are produced, there was very little capital infrastructure involved. Any embodied emissions in these products are likely to be minimal, well below the $1 \%$ criterion.

\subsubsection{Analysis}

Analysis was carried out using a LCA model built in Excel, and statistics were tested with SPSS software.

\subsection{RESULTS AND DISCUSSION}

\subsection{SRI practices in the study site}

The SRI principles as discussed in the introduction were not necessarily always precisely followed on the ground. For example, the average age at transplanting was somewhat greater than 15 days, although about half that of conventional practice; and typically more than 1 plant was transplanted per hill (Table 1). Yet with the exception of farm yard manure applications, measures on the SRI farms studied were significantly different, and in the expected direction, compared to those on control farms. The results reported are thus not for the full use of recommended SRI practices. Such a pattern of partial and adaptive adoption of new technology and practices is a widely observed phenomenon, characteristic of the early stages of waves of most agricultural innovation (Richards 1985). 
[Table 1 about here]

\subsection{SRI yield and GHG emissions compared to control farms}

SRI management was found to increase grain yield by approximately $60 \%$ compared to the control farms, 7.6 compared to $4.8 \mathrm{tha}^{-1}$, respectively, $\mathrm{p}<0.001$ ) (Table $2 \mathrm{a}$ ). This is a remarkable gain in yield when we consider that ambitious breeding programmes typically provide yield gains of less than $1 \% \mathrm{yr}^{-1}$ (Fischer and Edmeades 2010). With increasing resource scarcity, including that of land, increasing yields from the same level of inputs is likely to result in reduced adverse environmental impacts.

[Tables $2 \mathrm{a}$ and $2 \mathrm{~b}$ about here]

Yet yield gains alone are not enough to guarantee environmental improvements; yield gains from the increased use of certain inputs can be associated with local environmental losses. However, in the case of SRI, the higher yield compared to the control farms was associated with lower levels of inputs - significantly lower with respect to synthetic N, P and $\mathrm{K}$, and water (While significantly less methane is emitted per hectare with SRI compared to the control farming systems, methane is still a major source of GHG from SRI production. It is responsible for almost the same proportion of total GHG emissions in comparison to the controls (47\%), even though with SRI the soil is not consistently flooded. One reason for the SRI methane emissions is the higher applications rates of organic amendments which serve as feedstock for methanogens. This does not imply that soil amendments should be reduced in SRI farms - they could be an important factor in increasing SRI yields. Research into optimum feedstock application rates would be undertaken so that excessive rates are not used. This is likely to become increasingly important with reduced livestock stocking densities in rural areas reducing the availability of manure.

The modelled GHG emissions from SRI are highly sensitive to the assumed rate of methane and nitrous oxide emissions compared to the default emission factors posted by 
IPCC 2006. At present, the emission factors are based on three pieces of research. As more research is carried out specifically into the GHG emissions from SRI compared to control production systems, the accuracy of comparative LCA models will increase.

The magnitude of the different results modelled above suggests that SRI will consistently show GHG savings per kilogram of rice produced compared to conventional flooded production systems. While an increase in $\mathrm{N}_{2} \mathrm{O}$ emissions could mitigate $\mathrm{CH}_{4}$ emission savings on an area basis, we saw increased yield and reduced irrigation demand with SRI management consistently reducing its GHG burden per kilogram of production.

b). The exception to this was a slightly higher application rate of FYM on the SRI farms (18.7 compared to $17.0, \mathrm{p}>0.1$ ). This, however, resulted in no significant difference between the total applications of $\mathrm{N}$ per hectare between the two production systems.

This strongly suggests that there is an inherent yield advantage in the SRI farming system compared to the traditional wetland paddy system. To which aspect of SRI this may be attributed is not yet clear - wider spacing, earlier transplanting, single plants per hill (all of which contribute to increased tillering), or to the change in irrigation patterns. Ascertaining this will require further factorial trials.

Table 2a shows the reduced GHG emissions per hectare-season with SRI management. The emission savings are over $25 \%\left(13,981\right.$ to $10,232 \mathrm{~kg} \mathrm{CO}_{2}$-eq $\mathrm{ha}^{-1}$ from the control and SRI fields, respectively $(\mathrm{p}<0.01)$. The lower emissions from SRI are magnified when evaluated in terms of GHG per kg of paddy, due to the higher yield from SRI. Thus, SRI is responsible for less than half as much GHG emission per kilogram $(\mathrm{p}<0.001)$ as with conventional rice production.

When emissions are analysed by farm operations, the pattern of emissions differs between the two systems. SRI emissions' per hectare are higher for both $\mathrm{N}_{2} \mathrm{O}(\mathrm{p}<0.01)$ and transport 
of manure $\mathrm{p}>0.1$ ), but they are lower for all other categories, including significantly lower $\mathrm{CH}_{4}(\mathrm{p}<0.01)$ and irrigation-based $(\mathrm{p}<0.01)$ emissions (Figure 2$)$.

[Figure 2 about here]Error! Reference source not found.

Overall GHG emissions per kg of paddy show a similar pattern as above, but due to the higher yields with SRI management, $\mathrm{N}_{2} \mathrm{O}$ emissions per $\mathrm{kg}$ of SRI paddy rice were not significantly different from the control $\mathrm{N}_{2} \mathrm{O}$ emissions per kilogram, while the differences between SRI and control in terms of their $\mathrm{CH}_{4}$ and irrigation-based emissions per $\mathrm{kg}$ of paddy increase (Figure 3).

[Figure 3 about here]

While significantly less methane is emitted per hectare with SRI compared to the control farming systems, methane is still a major source of GHG from SRI production. It is responsible for almost the same proportion of total GHG emissions in comparison to the controls (47\%), even though with SRI the soil is not consistently flooded. One reason for the SRI methane emissions is the higher applications rates of organic amendments which serve as feedstock for methanogens. This does not imply that soil amendments should be reduced in SRI farms - they could be an important factor in increasing SRI yields. Research into optimum feedstock application rates would be undertaken so that excessive rates are not used. This is likely to become increasingly important with reduced livestock stocking densities in rural areas reducing the availability of manure.

The modelled GHG emissions from SRI are highly sensitive to the assumed rate of methane and nitrous oxide emissions compared to the default emission factors posted by IPCC 2006. At present, the emission factors are based on three pieces of research. As more research is carried out specifically into the GHG emissions from SRI compared to control production systems, the accuracy of comparative LCA models will increase. 
The magnitude of the different results modelled above suggests that SRI will consistently show GHG savings per kilogram of rice produced compared to conventional flooded production systems. While an increase in $\mathrm{N}_{2} \mathrm{O}$ emissions could mitigate $\mathrm{CH}_{4}$ emission savings on an area basis, we saw increased yield and reduced irrigation demand with SRI management consistently reducing its GHG burden per kilogram of production.

Irrigation-based emissions are a substantial portion of the emissions from both production systems, respectively, $26 \%$ and $37 \%$ of total emissions per $\mathrm{kg}$ of paddy for the SRI and the control farms. We should note also that it is possible to irrigate farms with effectively no irrigation-based emissions, for example, with gravity-fed systems, or with clean power systems (local solar photovoltaic sources, or local wind-derived electricity). If we exclude irrigation-based emissions, SRI still has significantly lower GHG emissions, measured both per hectare and per kg of paddy produced $(\mathrm{p}<0.05)$.

The higher yields associated with SRI allow greater productivity from available resources. Thus while there is no significant difference in the total $\mathrm{N}$ applied between to the two farming systems, the SRI system allowed rice to make better use of the available N, and to significantly increase $(\mathrm{p}<0.05)$ the estimated nitrogen use efficiency (While significantly less methane is emitted per hectare with SRI compared to the control farming systems, methane is still a major source of GHG from SRI production. It is responsible for almost the same proportion of total GHG emissions in comparison to the controls (47\%), even though with SRI the soil is not consistently flooded. One reason for the SRI methane emissions is the higher applications rates of organic amendments which serve as feedstock for methanogens. This does not imply that soil amendments should be reduced in SRI farms they could be an important factor in increasing SRI yields. Research into optimum feedstock application rates would be undertaken so that excessive rates are not used. This is likely to 
become increasingly important with reduced livestock stocking densities in rural areas reducing the availability of manure.

The modelled GHG emissions from SRI are highly sensitive to the assumed rate of methane and nitrous oxide emissions compared to the default emission factors posted by IPCC 2006. At present, the emission factors are based on three pieces of research. As more research is carried out specifically into the GHG emissions from SRI compared to control production systems, the accuracy of comparative LCA models will increase.

The magnitude of the different results modelled above suggests that SRI will consistently show GHG savings per kilogram of rice produced compared to conventional flooded production systems. While an increase in $\mathrm{N}_{2} \mathrm{O}$ emissions could mitigate $\mathrm{CH}_{4}$ emission savings on an area basis, we saw increased yield and reduced irrigation demand with SRI management consistently reducing its GHG burden per kilogram of production.

b).

\subsection{CONCLUSIONS}

SRI significantly increased paddy yield from 4.8 to 7.6 tons per hectare, with generally reduced or constant inputs. The only higher input with SRI compared to the control farms was farm yard manure, and this difference was not statistically significant.

SRI management offers significant GHG savings both per hectare and per kilogram of paddy produced. These savings principally arise from reduced methane emissions and reduced embodied emissions in the electricity used for pumping irrigation water. While SRI nitrous oxide emissions were somewhat higher than on control farms, the difference was only significant on a per hectare basis, and it did not offset the gains of lower GWP from the substantially-reduced emissions of methane. 
This paper has not explored various other aspects of GHG emissions, for example, the role of indirect land use changes (ILUC) where yield gains can offer substantial GHG savings resulting from changes in land use elsewhere. Nor does the analysis here cover the wider social, economic and environmental indicators associated with SRI that are essential to fully understand the diffusion potential and impact of SRI. These other and broader issues are explored in more detail in papers listed at http://www.southasia.ox.ac.uk/resources-greenhousegases-technology-and-jobs-indias-informal-economy-case-rice. 
Annex: Input values, calculations, and data sources used in the LCA model

\begin{tabular}{|c|c|c|c|}
\hline Operation & Reference unit & Figure & Data source \\
\hline Seed & $\mathrm{kg} \mathrm{CO}_{2-\text { eq ha }}{ }^{-1}$ & See data source & $\begin{array}{l}\text { The mean GHG for that production technique, } \\
+5 \% \text { to account for handling and losses }\end{array}$ \\
\hline $\begin{array}{l}\text { Power tiller } \\
\text { diesel fuel use }\end{array}$ & liters $\mathrm{hr}^{-1}$ & 1.5 & Farmer survey \\
\hline $\begin{array}{l}\text { GHG intensity } \\
\text { diesel fuel }\end{array}$ & $\mathrm{kg} \mathrm{CO}_{2}$-eq I & 3.0168 & Renewable energy directive (Anon. 2009) \\
\hline $\begin{array}{l}\text { Power tiller life } \\
\text { expectancy }\end{array}$ & Yrs & 20 & Farmer survey, probably an underestimate. \\
\hline $\begin{array}{l}\text { Power tiller } \\
\text { weight }\end{array}$ & $\mathrm{Kg}$ & 515 & Greavescotton (2013) \\
\hline $\begin{array}{l}\text { Tractor I diesel } \\
\text { fuel } \mathrm{hr}^{-1}\end{array}$ & liters $\mathrm{hr}^{-1}$ & 4 & Farmer survey \\
\hline Tractor weight & $\mathrm{Kg}$ & 1952.5 & John Deere (2012); Mahindra (2012) \\
\hline $\begin{array}{l}\text { Embodied } \\
\text { GHG of steel }\end{array}$ & $\begin{array}{l}\mathrm{kg} \mathrm{CO}_{2} \text {-eq kg } \\
\text { steel }^{-1}\end{array}$ & 2.7 & CSE $(2012)$ \\
\hline Bullocks & $\begin{array}{l}\mathrm{kg} \mathrm{CO}_{2}-\mathrm{eq} \mathrm{hr} \\
\text { for a pair of } \\
\text { bullocks }\end{array}$ & 4.47 & $\begin{array}{l}\text { Running and embodied emissions were } \\
\text { calculated together for bullocks' use. It was } \\
\text { assumed that all livestock-based cultivation was } \\
\text { done by bullocks. Annual India-specific methane } \\
\text { emissions were taken from Singhal et al. (2005) } \\
\text { for indigenous bulls. Bullocks were assumed to } \\
\text { work for } 13 \text { years (from } 5 \text { years to } 18 \text { years (from } \\
\text { farmer survey). Total calf emissions were also } \\
\text { taken from Singhal et al. ( } 2005 \text { ). The annual } \\
\text { emissions plus } 1 / 13^{\text {th }} \text { of calf emissions were } \\
\text { divided by the total number of days that bullocks } \\
\text { worked per year (as described by the owner) and } \\
24 \text { hours a day, then multiplied by the number of } \\
\text { hours the animal worked day per day. Thus, if an } \\
\text { animal worked } 6 \text { hours a day, each hour would } \\
\text { represent } 25 \% \text { of the daily emissions, as the } \\
\text { bullocks emit methane } 24 \mathrm{~h} \text { day }{ }^{-1} \text {. For rented } \\
\text { bullocks, it was assumed that they worked } 100 \\
\text { days a year, and } 5.5 \text { hours a day (Fuller and Aye } \\
2012 \text { ). } \\
\text { This emission rate was reduced by } 1.3 \% \text { to } \\
\text { account for the final value of the bullocks at the } \\
\text { end of life (assumed to be Rs } 5000: \text { G. Rodrigo, } \\
2012, \text { pers. comm.). Assuming bullocks work } 100 \\
\text { days/yr, at } 5.5 \text { hours a day at Rs. } 50 \text { hr }{ }^{-1} \text { (assumed } \\
\text { to be rented out at Rs. } 100 \text { hr }{ }^{-1} \text { for a pair, so Rs. } \\
50 \text { hr }{ }^{-1} \text { bullocks }{ }^{-1} \text { ) for } 13 \text { years, and that a bullock } \\
\text { is worth Rs } 15,000 \text { when purchased, then the } \\
\text { end-of-life value is } 1.3 \% \text { of total value. } \\
\text { It is further reduced by } 4.1 \% \text { for the } \mathrm{CH}{ }_{4} \text { allocated } \\
\text { to manure, using economic value of NPK fertiliser } \\
\text { in manure ( } 1,166 \text { Rs/animal) compared to the } \\
\text { potential rental value of an bullocks over a year } \\
\text { ( } 50 \text { Rs. hr }{ }^{-1}, 5.5 \text { hr day }{ }^{-1} 100 \text { days yr }{ }^{-1} \text { ) }\end{array}$ \\
\hline $\begin{array}{l}\text { Allocation to } \\
\text { straw }\end{array}$ & $\begin{array}{l}\text { \% reduction in } \\
\text { 'economic' yield }\end{array}$ & $-4 \%$ & $\begin{array}{l}\text { Emissions were allocated to straw using an } \\
\text { economic calculation; emissions allocated to } \\
\text { straw were deducted from those allocated to } \\
\text { paddy. }\end{array}$ \\
\hline
\end{tabular}




\begin{tabular}{|c|c|c|c|c|}
\hline & & & & $\begin{array}{l}\text { We calculated the yield of straw by proxy, using } \\
\text { the harvest index. Although the harvest index } \\
\text { (the proportion of grain to total above-ground } \\
\text { biomass) for intensive in-bred rice is } \\
\text { approximately } 50 \% \text { (Islam et al. 2010; Khush } \\
\text { 2001), this does not account for the actual } \\
\text { availability of straw to harvest - inevitably a } \\
\text { portion is left in the field. We have therefore } \\
\text { assumed that the harvestable yield of straw } \\
\text { would be } 90 \% \text { of total straw, so total straw yield } \\
\text { is assumed to be } 90 \% \text { of paddy yield } \\
\left(0.5^{*} 2^{*} 90 \%\right) \text {. The value of straw was calculated } \\
\text { using straw prices from Tamil Nadu, which } \\
\text { averaged Rs } 0.51 \mathrm{~kg}^{-1} \text { (standard deviation } 0.043 \text { ) } \\
\text { (Gathorne-Hardy and Harriss-White } 2013 \text { ). }\end{array}$ \\
\hline $\begin{array}{l}\text { Tractors, } \\
\text { embodied } \\
\text { emission. }\end{array}$ & $\mathrm{Kg} \mathrm{CO}_{2}-$ eq hr ${ }^{-1}$ & & & $\begin{array}{l}\text { Assumed to be } 100 \% \text { steel and to last for } 20 \\
\text { years. Embodied GHG emissions for Indian steel } \\
\text { taken from CSE (2012). Embodied emissions are } \\
\text { calculated on an hourly basis by dividing the total } \\
\text { embodied emissions by the fraction of hours for } \\
\text { each job compared to total number of hours the } \\
\text { tractor works in } 20 \text { years. }\end{array}$ \\
\hline \multirow[t]{7}{*}{ Fertilisers } & \multirow{7}{*}{$\begin{array}{l}\mathrm{kg} \mathrm{CO}_{2} \text {-eq kg } \\
\text { bought fertiliser, } \\
\text { i.e., not just } \\
\text { active ingredient }\end{array}$} & & & \multirow{7}{*}{$\begin{array}{l}\text { Urea emissions were taken from India-specific } \\
\text { urea GHG emission factors from CSE (2009). Data } \\
\text { for phosphate, ammonia and potash were taken } \\
\text { from Woods and Cowie (2004). Neem cake: } 0.01 \\
\mathrm{~kg} \mathrm{CO}_{2} \text {-eq kg }{ }^{-1} \text {. This used extraction data for } \\
\text { jatropha from Kumar et al. (2012), multiplied by } \\
\text { the economic values of neem oil and neem cake } \\
\text { from Krishi Vighan Kendra (2012). }\end{array}$} \\
\hline & & Phosphate & 1.94 & \\
\hline & & DAP & 1.79 & \\
\hline & & Urea & 0.93 & \\
\hline & & Complex & 0.24 & \\
\hline & & Potash & 0.16 & \\
\hline & & Neem & 0.10 & \\
\hline Pesticides & $\begin{array}{l}\mathrm{CO}_{2} \text {-eq } \mathrm{kg} \text { active } \\
\text { ingredient }\end{array}$ & \multicolumn{2}{|l|}{4.921} & Data taken from Elsayad et al. (2003). \\
\hline Manure & $\mathrm{kg} \mathrm{CO}_{2}$-eq t ${ }^{-1}$ & \multicolumn{2}{|l|}{0.03} & $\begin{array}{l}\text { Manure from cows/bullocks has associated } \mathrm{CH}_{4} \\
\text { emissions from bovine enteric emissions. } \\
\text { Methane emissions were allocated using } \\
\text { economic measures. The annual emissions from } \\
\text { a dairy cow, taken from Singhal et al. (2005), was } \\
\text { split by the total value from milk production } \\
\text { (taken from farmer surveys) and the total value } \\
\text { of the NPK in the manure, using Tennakoon and } \\
\text { Hemamala Bandara (2003). Calculated economic } \\
\text { values and reported values for manure were } \\
\text { similar ( } 6 \text { and } 8 \% \text {, respectively, p }>0.05 \text { ), but } \\
\text { economic measures were chosen due to the } \\
\text { shortage of reported values. }\end{array}$ \\
\hline $\begin{array}{l}\text { Nitrogen use } \\
\text { efficiency }\end{array}$ & $\%$ & & & $\begin{array}{l}\text { Defined in this paper as quantity of nitrogen used } \\
\text { by the crop compared to total nitrogen supply } \\
\text { (Good et al. 2004). This assumes rice plants take } \\
\text { up } 17 \mathrm{~kg} \mathrm{~N} \text { for each ton of rough rice produced } \\
\text { through the grain, leaves and straw (quoted in } \\
\text { Choudhury 2004). }\end{array}$ \\
\hline $\begin{array}{l}\text { Methane } \\
\text { emissions }\end{array}$ & $\mathrm{kg} \mathrm{CO}_{2}$-eq ha ${ }^{-1}$ & \multicolumn{2}{|l|}{ Modelled } & IPCC default figures (IPCC 2006). \\
\hline $\begin{array}{l}\text { Nitrous oxide } \\
\text { emissions }\end{array}$ & $\mathrm{kg} \mathrm{CO}_{2}$-eq ha ${ }^{-1}$ & \multicolumn{2}{|l|}{ Modelled } & IPCC default figures (IPCC 2006). \\
\hline
\end{tabular}




\begin{tabular}{|c|c|c|c|}
\hline $\begin{array}{l}\mathrm{SRICH} \text { and } \\
\mathrm{N}_{2} \mathrm{O} \text { emissions }\end{array}$ & $\mathrm{kg} \mathrm{CO}_{2}$-eq ha ${ }^{-1}$ & Modelled & $\begin{array}{l}\text { Calculating soil-based GHG emissions from SRI } \\
\text { rice was more complicated due to lack of } \\
\text { appropriate IPCC default figures. In principle, the } \\
\text { methane emissions should be low due to the } \\
\text { repeated drainage, and nitrous oxide emissions } \\
\text { would be high due to the partially-flooded soil } \\
\text { conditions, but the authors could find no } \\
\text { published evidence to confirm this. While there } \\
\text { are some SRI GHG emission data available, none } \\
\text { that the author could find were adequate for our } \\
\text { use (i.e., with detailed, replicated methodologies, } \\
\text { suitable analysis). For this reason we have relied } \\
\text { on papers looking at controlled irrigation as an } \\
\text { isolated factor (for methane, we used Peng et al. } \\
\text { (2011b), Hou et al. (2012) and Suryavanshi et al. } \\
\text { (2013) resulting in methane emissions of } 57.9 \% \\
\text { of control (conventional/intensive) production } \\
\text { techniques; for nitrous oxide, we used Peng et al. } \\
\text { (2011b), Hou et al. (2012) and Peng et al. (2011a), } \\
\text { resulting in N } \mathrm{N}_{2} \mathrm{O} \text { emissions of } 211.0 \% \text { of control. } \\
\text { This has some advantages, e.g., the data are not } \\
\text { compounded by multiple factors which can be } \\
\text { included in separate calculations (e.g., such as } \\
\text { changes in levels of manure inputs), but it also } \\
\text { has disadvantages since some specific SRI } \\
\text { practices have no data relating to them at all } \\
\text { (such as wider spacing between hills) and so this } \\
\text { cannot be incorporated into the GHG } \\
\text { calculations. This calculation is very close to the } \\
\text { IPCC multiple-aeration figure of } 52 \% \text { for multiple } \\
\text { aerations (IPCC } 2006 \text { ). }\end{array}$ \\
\hline $\begin{array}{l}\text { Electricity- } \\
\text { based } \\
\text { emissions from } \\
\text { irrigation. }\end{array}$ & & & $\begin{array}{l}\text { Calculating the amount of energy used for } \\
\text { irrigation was difficult. Ideally we would have } \\
\text { used meter readings, but no farmers had } \\
\text { electricity meters. Instead we calculated the } \\
\text { total amount of energy used through the size of } \\
\text { the pump(s) and the number of hours they were } \\
\text { used over the season. While pump horsepower } \\
\text { was unambiguous, the hours of pump use were } \\
\text { from daily estimates. }\end{array}$ \\
\hline $\begin{array}{l}\text { Embodied } \\
\text { GHG emissions } \\
\text { associated } \\
\text { with electricity }\end{array}$ & $\mathrm{kg} \mathrm{CO}_{2}$ eq $\mathrm{KWh}^{-1}$ & 1.1095 & $\begin{array}{l}\text { This was generated using CEA (2011) data of } 0.81 \\
\text { at production multiplied by } 27 \% \text { T and E losses } \\
\text { (Alagh 2010). Transmission losses are included, } \\
\text { but not theft because stolen electricity } \\
\text { presumably has some utility, so it should also } \\
\text { take a share of overall emissions. }\end{array}$ \\
\hline Harvest & $\begin{array}{l}\text { GHG emissions } \\
\mathrm{hr}^{-1}\end{array}$ & 15.084 & $\begin{array}{l}5 \text { liters of diesel fuel } \mathrm{hr}^{-1} \text {, taken from interview } \\
\text { with combine harvester owner/operator. }\end{array}$ \\
\hline $\begin{array}{l}\text { Soil organic } \\
\text { carbon }\end{array}$ & $\mathrm{kg} \mathrm{CO}_{2}$-eq ha ${ }^{-1}$ & Modelled & Taken from IPCC (IPCC 2006). \\
\hline
\end{tabular}




\section{REFERENCES}

Adhya, T.K., Bharati, K., Mohanty, S.R., Ramakrishnan, B., Rao, V.R., Sethunathan, N., and Wassmann, R., "Methane emission from rice fields at Cuttack, India," Nutrient Cycling in Agroecosystems, 58, 95-105, 2000.

Alagh, Y., Transmission and Distribution of Electricity in India Regulation, Investment and Efficiency, Indian Institute of Rural Management, Anand, Gujarat, 2010.

Anon., "On the promotion of the use of energy from renewable sources and amending and subsequently repealing Directives 2001/77/EC and 2003/30/EC," Official Journal of the European Union, 2009. http://eur-lex.europa.eu/LexUriServ/LexUriServ.do?uri=Oj:L:2009: 140:0016:0062:en:PDF

Anon., "Climate," in: Statistics, Department of Environment, Andha Pradesh Government, Hyderabad. http://www.ap.gov.in/Other\%20Docs/CLIMATE.pdf

Blengini, G.A., and Busto, M., "The life cycle of rice: LCA of alternative agri-food chain management systems in Vercelli (Italy)," Journal of Environmental Management, 90, 512522, 2009.

Bodelier, P.L.E., "Interactions between oxygen releasing roots and microbial processes in flooded soils and sediments," in: de Kroon, H. and Visser, E.J.W., eds., Root Ecology. Springer, Berlin, 2003.

Bouman, B.A.M., Lampayan, R.M. and Tuong, T.P., Water Management in Irrigated Rice: Coping with Water Scarcity, International Rice Research Institute, Los Baños, Philippines, 2007.

CEA, $\mathrm{CO}_{2}$ Baseline Database for the Indian Power Sector, User Guide, version 6.0, Central Electricity Authority, Ministry of Power, Sewa Bhawan, New Delhi, India, 2011.

CSE, Green Rating Project: Fertilizers, Centre for Science and Environment, New Delhi, 2009. http://www.cseindia.org/userfiles/79-90\%20Fertilizer\%281\%29.pdf

CSE, Into the Furnace: Green rating project of Indian Iron and Steel Sector, Centre for Science and Environment, Delhi, India, 2012.

Chanton, J.P., Whiting, G.J., Blair, N.E., Lindau, C.W. and Bollich, P.K., "Methane emission from rice: Stable isotopes, diurnal variations, and $\mathrm{CO}_{2}$ exchange," Global Biogeochemical Cycles, 11, 15-27, 1997.

BSI, Specification for the Assessment of the Life Cycle Greenhouse Gas Emissions of Goods and Services: PAS 2050:2011, British Standards Institution, London, 2011.

Choudhury, A.T.M.A. and Kennedy, I.R., "Prospects and potentials for systems of biological nitrogen fixation in sustainable rice production," Biology and Fertility of Soils, 39, 219-227, 2004.

Elsayed, M.A., Matthews, R., and Mortimer, N.D., Carbon and Energy Balances for a Range of Biofuels Options, Project No. B/B6/00784/REP URN 03/836, carried out as part of the DTI Sustainable Energy Programme, 2003. http://airburners.com/PUB/Sheffield-studiemei2003.pdf

European Commission, International Reference Life Cycle Data System (ILCD) Handbook: General Guide for Life Cycle Assessment, Joint Research Centre Institute for Environment and Sustainability. Publications Office of the European Union, Luxembourg, 2010. 
Fischer, R.A. and Edmeades, G.O., "Breeding and cereal yield progress," Crop Science, 50, 85-98, 2010.

Forster, P., Ramaswamy, V., Artaxo, P., Berntsen, T., Betts, R., Fahey, D.W., Haywood, J., Lean, J., Lowe, D.C., Myhre, G., Nganga, J., Prinn, R., Raga, G., Schulz, M. and Van Dorland, R., "Changes in atmospheric constituents and in radiative forcing," in: Climate Change 2007: The Physical Science Basis, Contribution of Working Group I to the Fourth Assessment Report of the Intergovernmental Panel on Climate Change, Solomon, S., Qin, D., Manning, M., Chen, Z., Marquis, M., Avery, K.B., Tignor, M., Miller, H.L. (eds.), 131-234. Cambridge University Press, Cambridge, UK, 2007.

Fuller, R.J. and Aye, L., "Human and animal power - The forgotten renewables," Renewable Energy, 48, 326-332, 2012.

Gathorne-Hardy, A., Greenhouse gas emissions from rice, Working paper for South Asia Program, School of Interdisciplinary Area Studies, Oxford University, UK, 2013a. http://www.southasia.ox.ac.uk/sites/sias/files/documents/GHG\%20emissions\%20from\%20rice\%20\%20\%20working\%20paper.pdf

Gathorne-Hardy, A., On Life Cycle Analysis: Baselines and Boundaries, Internal discussion document for School of Interdisciplinary Area Studies, Oxford University, UK, 2013b.

Gathorne-Hardy, A., and Harriss-White, B., Embodied emissions and dis-embodied jobs, Symposium on Technology, Jobs and a Lower Carbon Future, 2013. http://www.southasia.ox.ac.uk/sites/sias/files/documents/Conference\%20Book.pdf

Good, A.G., Shrawat, A.K. and Muench, D.G., "Can less yield more? Is reducing nutrient input into the environment compatible with maintaining crop production?" Trends in Plant Science, 9, 597-605, 2004.

Greavescotton, Greaves Power Tiller, Greavescotton, Mumbai, 2013. http://www.greavescotton.com/Upload/AgroEquipFiles/powertiller.pdf.

Hansen, S., Mæhlum, J.E. and Bakken, L.R., " $\mathrm{N}_{2} \mathrm{O}$ and $\mathrm{CH}_{4}$ fluxes in soil influenced by fertilization and tractor traffic," Soil Biology and Biochemistry, 25, 621-630, 1993.

Hokazono, S. and Hayashi, K., "Variability in environmental impacts during conversion from conventional to organic farming: A comparison among three rice production systems in Japan," Journal of Cleaner Production, 28, 101-112, 2012.

Hou, H., Peng, S., Xu, J., Yang, S. and Mao, Z.. "Seasonal variations of $\mathrm{CH}_{4}$ and $\mathrm{N}_{2} \mathrm{O}$ emissions in response to water management of paddy fields located in Southeast China," Chemosphere, 89, 884-892, 2012.

IPCC, National Guidelines for Greenhouse Gas Inventories, Inter-governmental Panel on Climate Change, Geneva, 2006. http://www.ipcc-nggip.iges.or.jp/public/2006gl/index.htm

IRRI, Rice Production and Processing, International Rice Research Institute, Los Baños, Philippines, 2013. http://www.irri.org/index.php?option=com_k2\&view=item\&layout=item\&id=9151\&lang=en

Islam, M., Peng, S., Visperas, R., Bhuiya, M., Hossain, S. and Julfiquar, A., "Comparative study on yield and yield attributes of hybrid, inbred, and NPT rice genotypes in a tropical irrigated ecosystem," Bangladesh Journal of Agricultural Research, 35, 343-353, 2010.

ISO, Environment Management: Life Cycle Assessment-Principles and Framework, EN ISO 14040 2006, International Organization for Standardization, Geneva, 2006. 
John Deere, Tractor Specifications, Moline, IL, 2012. http://www.deere.com/en_IN/home_page/ag_home/products/5104_45HP/5104_45HP.html

Kassam, A., Stoop, W. Uphoff, N., "Review of SRI modifications in rice crop and water management and research issues for making further improvements in agricultural and water productivity," Paddy and Water Environment, 9, 163-180, 2011.

Khush, G.S., "Green Revolution: The way forward," Nature Reviews: Genetics, 2, 815-822, 2011.

Krishi Vighan Kendra, Vamban, Pudukottai, Tamil Nadu, India, 2012. http://kvkpudukkottai.com/front_line_demonstrations.html

Kumar, S., Singh, J., Nanoti, S.M. and Garg, M.O., "A comprehensive life cycle assessment (LCA) of Jatropha biodiesel production in India," Bioresource Technology, 110, 723-729, 2012.

Linquist, B., van Groenigen, K.J., Adviento-Borbe, M.A., Pittelkow, C. and van Kessel, C., "An agronomic assessment of greenhouse gas emissions from major cereal crops," Global Change Biology, 18, 194-209, 2012.

Mahindra, Tractor Specifications, Mumbai, India, 2012. http://www.mahindratractorworld.com/Bangladesh-en/Products-Tractors-MKM-NBP-SERIES-3050HP/575-DI-MKM-NBP-45HP

MEF, "India: Greenhouse Gas Emissions 2007," in: Indian Network for Climate Change Assessment, Ministry of Environment and Forests, Government of India, New Delhi, 2010.

Nelson, G.C., Robertson, R., Msangi, S., Zhu, T., Liao, X. and Jawajar, P., Greenhouse Gas Mitigation. Issues for Indian Agriculture, IFPRI Discussion Paper, International Food Policy Research Institute, Washington, DC, 2009.

Peng, S., Hou, H., Xu, J., Mao, Z., Abudu, S., and Luo, Y., "Nitrous oxide emissions from paddy fields under different water managements in southeast China," Paddy and Water Environment, 9, 403-411, 2011a.

Peng, S., Yang, S., Xu, J. and Gao, H., "Field experiments on greenhouse gas emissions and nitrogen and phosphorus losses from rice paddy with efficient irrigation and drainage management." Science China Technological Sciences, 54, 1581-1587, 2011 b.

Qin, Y., Liu, S., Guo, Y., Liu, Q. and Zou, J., "Methane and nitrous oxide emissions from organic and conventional rice cropping systems in Southeast China." Biology and Fertility of Soils, 46, 825-834, 2010.

Reddy, D.N. and Mortkori, V., "SRI cultivation in Andhra Pradesh: Achievements, problems and implications for GHGs and work," in: Harriss-White, B. (ed.), Technology, Jobs and A Lower Carbon Future: Methods, Substance and Ideas for the Informal Economy (The Case of Rice in India), 160-192, Delhi, 2013. http://www.southasia.ox.ac.uk/sites/sias/files/documents/Conference\%20Book.pdf

Richards, P., Indigenous Agricultural Revolution: Ecology and Food Production in West Africa, Hutchinson, London, 1985.

Singhal, K.K., Mohini, M., Jha, A.K. and Gupta, P.K., "Methane emission estimates from enteric fermentation in Indian livestock: Dry matter intake approach," Current Science, 88, 119-127, 2005.

Sinha, S.K. and Talati, J., "Productivity impacts of the system of rice intensification (SRI): A case study in West Bengal, India," Agricultural Water Management, 87, 55-60, 2007. 
Stoop, W.A., Uphoff, N. and Kassam, A., "A review of agricultural research issues raised by the system of rice intensification (SRI) from Madagascar: Opportunities for improving farming systems for resource-poor farmers," Agricultural Systems, 71, 249-274, 2002.

Sumberg, J., Andersson, J., Giller, K.E. and Thompson, J., "Response to 'Combining sustainable agricultural production with economic and environmental benefits'," The Geographical Journal, 179, 183-185, 2013.

Suryavanshi, P., Singh, Y.V., Prasanna, R., Bhatia, A. and Shivay, Y.S., "Pattern of methane emission and water productivity under different methods of rice crop establishment," Paddy and Water Environment, 11, 321-329, 2013.

Tennakoon, N.A. and Hemamala Bandara, S.D., "Nutrient content of some locally available organic materials and their potential as alternative sources of nutrients for coconut," COCOS, 15, 23-30, 2003.

Uphoff, N., "The System of Rice Intensification (SRI) as a System of Agricultural Innovation," paper for Institute of Development Studies conference, Sussex, UK, 2009. http://repository.ipb.ac.id/handle/123456789/43778

Wang, M., Xia, X., Zhang, Q. and Liu, J., "Life cycle assessment of a rice production system in Taihu region, China," International Journal of Sustainable Development and World Ecology, 17, 157-161, 2010.

Wang, Z.Y., Xu, Y.C., Li, Z., Guo, Y.X., Wassmann, R., Neue, H.U., Lantin, R.S., Buendia, L.V., Ding, Y.P. and Wang, Z.Z., "A four-year record of methane emissions from irrigated rice fields in the Beijing Region of China," Nutrient Cycling in Agroecosystems, 58, 55-63, 2000 .

White, R.M., "Carbon governance in UK liquid milk systems," Environmental Change Institute, Oxford, Oxford, 2010.

Williams, A.G., Audsley, E. and Sandars, D.L., "Determining the environmental burdens and resource use in the production of agricultural and horticultural commodities," Cranfield University, Bedford, UK, 2006.

Wood S, and Cowie A., "A review of greenhouse gas emission factors for fertiliser production," in: IEA Bioenergy Task 38 Report, Cooperative Research Centre for Greenhouse Accounting, Research and Development Division, State Forests of New South Wales, Beecroft, NSW, Australia, 2004. http://www.ieabioenergy-task38.org/publications/GHG_ Emission_Fertilizer\%20Production_July2004.pdf

Woods, J., Brown, G., Gathorne-Hardy, A., Sylvester-Bradley, R., Kindred, D. and Mortimer, N., Facilitating Carbon (GHG) Accreditation Schemes for Biofuels and Feedstock Production. Report 435, Part 1, Home Grown Cereals Authority, London. http://www.hgca.com/document.aspx?fn=load\&media_id=4567\&publicationld=4623

WWF, More Rice with Less Water: SRI - System of Rice Intensification, WWF International, Patancheru, Andhra Pradesh, India, 2007.

Yan, X., Shi, S., Du, L. and Xing, G., "Pathways of $\mathrm{N}_{2} \mathrm{O}$ emission from rice paddy soil," Soil Biology and Biochemistry, 32, 437-440, 2000.

Yan, X., Yagi, K., Akiyama, H. and Akimoto, H., "Statistical analysis of the major variables controlling methane emission from rice fields," Global Change Biology, 11: 1131-1141, 2005. 
Yao, H., Conrad, R., Wassmann, R. and Neue, H.U., "Effect of soil characteristics on sequential reduction and methane production in sixteen rice paddy soils from China, the Philippines, and Italy," Biogeochemistry, 47, 269-295, 1999.

Zheng, X., Wang, M., Wang, Y., Shen, R., Gou, J., Li, J., Jin, J. and Li, L., "Impacts of soil moisture on nitrous oxide emission from croplands: A case study on the rice-based agroecosystem in Southeast China," Chemosphere: Global Change Science, 2, 207-224, 2000. 
Table 1. Agronomic practices of SRI and control farmers (S.E. in parentheses)

\begin{tabular}{|l|c|c|}
\hline Agronomic practices & SRI & $\begin{array}{c}\text { Control (conventional Green } \\
\text { Revolution techniques) }\end{array}$ \\
\hline $\begin{array}{l}\text { Planting date (age of seedling, } \\
\text { in days) }\end{array}$ & $18(1.1)$ & $32.5(1.7)^{* *}$ \\
\hline Number of plants per hill & $1.8(0.2)$ & $5(0)^{* * *}$ \\
\hline Distance between hills $(\mathrm{cm})$ & $25(0)$ & $12(0)^{* * *}$ \\
\hline $\begin{array}{l}\text { Number of days irrigation } \\
\text { (days/season) }\end{array}$ & $71.8(6.2)$ & $17.8(12.8)^{* * *}$ \\
\hline Quantity of manure $\left(\mathrm{t} \mathrm{ha}^{-1}\right)$ & $18.7(4)$ & \\
\hline
\end{tabular}

No asterisk $=$ no sig difference, ${ }^{*}=\mathrm{p}<0.1,{ }^{*}=\mathrm{p}<0.05, * * * \mathrm{p}<0.01$. 
Table 2a. Farm details, GHG emissions, yield, and water use from SRI and control farms*

\begin{tabular}{|l|c|c|c|c|c|c|c|}
\hline $\begin{array}{c}\text { Farming } \\
\text { system }\end{array}$ & $\begin{array}{c}\text { Number } \\
\text { of farms }\end{array}$ & $\begin{array}{c}\text { Farm size } \\
\text { (ha) }\end{array}$ & $\begin{array}{c}\text { GHG } \\
\text { emissions } \\
\left(\mathrm{CO}_{2} \text {-eq ha }\right.\end{array}$ & $\begin{array}{c}\text { GHG } \\
\text { emissions } \\
\left(\mathrm{kg} \mathrm{CO}_{2} \text {-eq }\right. \\
\left.\mathrm{kg} \mathrm{paddy}^{-1}\right)\end{array}$ & $\begin{array}{c}\text { Yield } \\
\left.\mathrm{ha}^{-1}\right)\end{array}$ & $\begin{array}{c}\text { Water use } \\
\left(\mathrm{t} \mathrm{ha}^{-1}\right)\end{array}$ & $\begin{array}{c}\text { Water use } \\
\left(\mathrm{t} \mathrm{kg} \mathrm{paddy}^{-1}\right)\end{array}$ \\
\hline SRI & 20 & $\begin{array}{c}1.23 \\
(0.62)\end{array}$ & $\begin{array}{c}10,232 * * * \\
(588)\end{array}$ & $\begin{array}{c}1.1^{* * *} \\
(0.05)\end{array}$ & $\begin{array}{c}7,609 * * * \\
(304)\end{array}$ & $\begin{array}{c}16,049 * * \\
(3,682)\end{array}$ & $\begin{array}{c}2.05 * * * \\
(0.47)\end{array}$ \\
\hline Control & 10 & $\begin{array}{c}0.11 \\
(0.33)\end{array}$ & $\begin{array}{c}13,981 \\
(696)\end{array}$ & $\begin{array}{c}2.8 \\
(0.2)\end{array}$ & $\begin{array}{c}4,834 \\
(197)\end{array}$ & $\begin{array}{c}24,980 \\
(3,274)\end{array}$ & $\begin{array}{c}4.90 \\
(0.46)\end{array}$ \\
\hline
\end{tabular}

*Asterisks indicate degree of significant difference between the farming systems; no asterisk $=$ no significant difference, ${ }^{*}=\mathrm{p}<0.1,{ }^{*}=\mathrm{p}<0.05,{ }^{* * *} \mathrm{p}<0.01$ (S.E. shown in parentheses) 
Table 2b. Nutrient inputs and water table for SRI and control farms*

\begin{tabular}{|l|c|c|c|c|c|c|c|}
\hline $\begin{array}{c}\text { Farming } \\
\text { system }\end{array}$ & $\begin{array}{c}\text { Synthetic N } \\
\left(\mathrm{kg} \mathrm{N} \mathrm{ha}^{-1}\right)\end{array}$ & $\begin{array}{c}\text { Total N } \\
(\mathrm{kg} \mathrm{N})\end{array}$ & $\begin{array}{c}\mathrm{N} \text { used by } \\
\text { crop }(\mathrm{kg} \\
\left.\mathrm{ha}^{-1}\right)\end{array}$ & $\begin{array}{c}\text { NUE }(\mathrm{kg} \mathrm{N} \\
\text { utilised kg } \\
\mathrm{N} \text { applied })\end{array}$ & $\begin{array}{c}\text { Total } \\
\text { synthetic K }\end{array}$ & $\begin{array}{c}\text { Total } \\
\text { synthetic P }\end{array}$ & $\begin{array}{c}\text { Water table } \\
(\mathrm{m})\end{array}$ \\
\hline SRI & $157^{* *}$ & 436 & 129 & $34 \% * *$ & $80^{*}$ & $166^{* *}$ & 27.01 \\
& $(36)$ & $(100)$ & $(30)$ & $(8 \%)$ & $(18)$ & $(38)$ & $(7.30))$ \\
\hline Control & 226 & 478 & 82 & $18 \%$ & 111 & 250 & 27.28 \\
& $(17)$ & $(42)$ & $(3)$ & $(1 \%)$ & $(18)$ & $(25)$ & $(3.27)$ \\
\hline
\end{tabular}

$*$ Asterisks indicate degree of significant difference between the farming systems; no asterisk $=$ no significant difference, ${ }^{*}=\mathrm{p}<0.1, * *=\mathrm{p}<0.05, * * * \mathrm{p}<0.01$ (S.E. shown in parentheses) 
Figure 1. System boundaries for determining the environmental burden of rice production. Categories outside the heavy line are not included within the boundary of this LCA

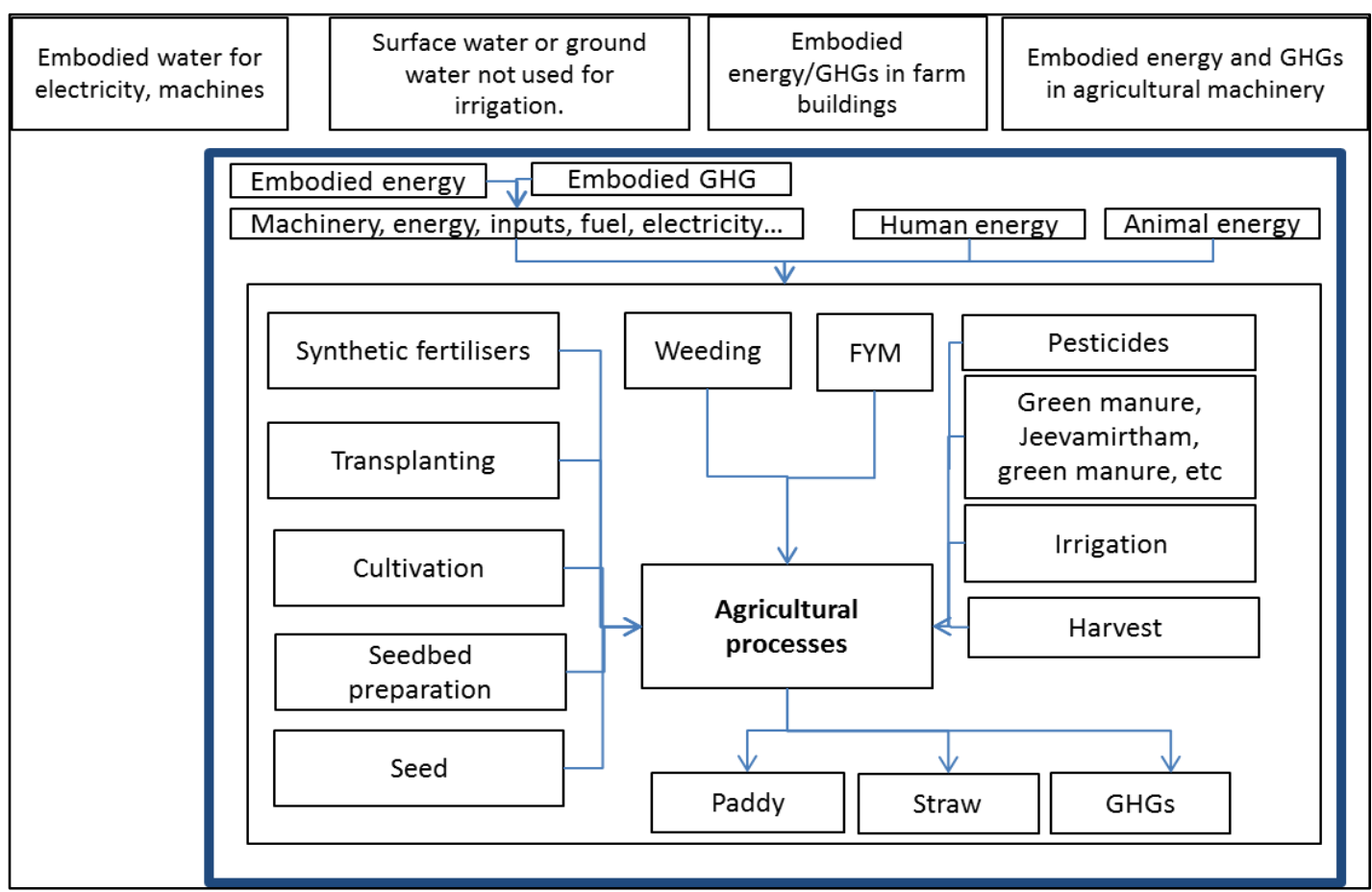


Figure 2. GHG emissions per hectare for SRI and control paddy production techniques $($ Error bars $=1$ S.E. $)$

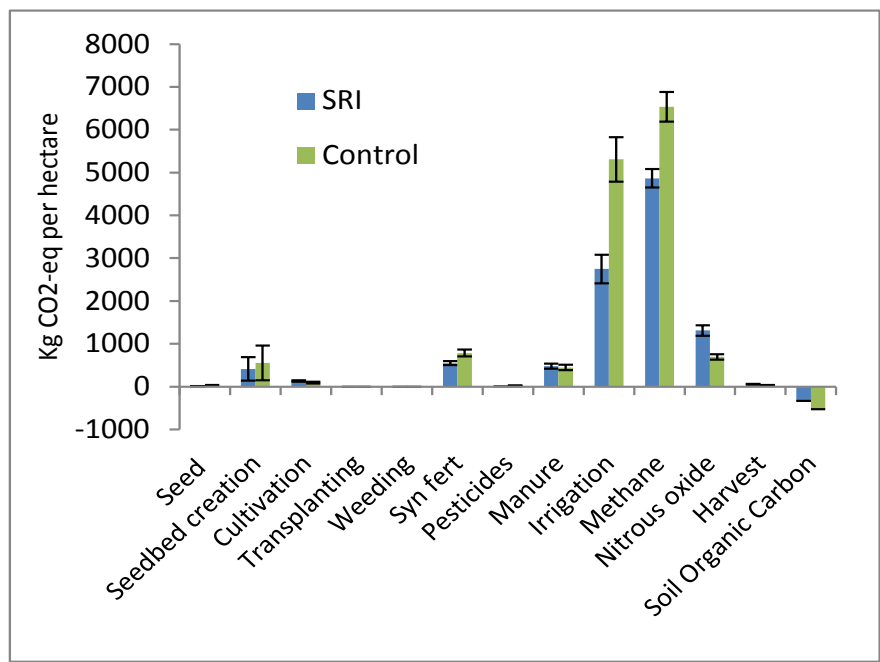


Figure 1. GHG emissions for SRI and control, per kg of paddy at the farm gate (Error bars = 1 S.E.)

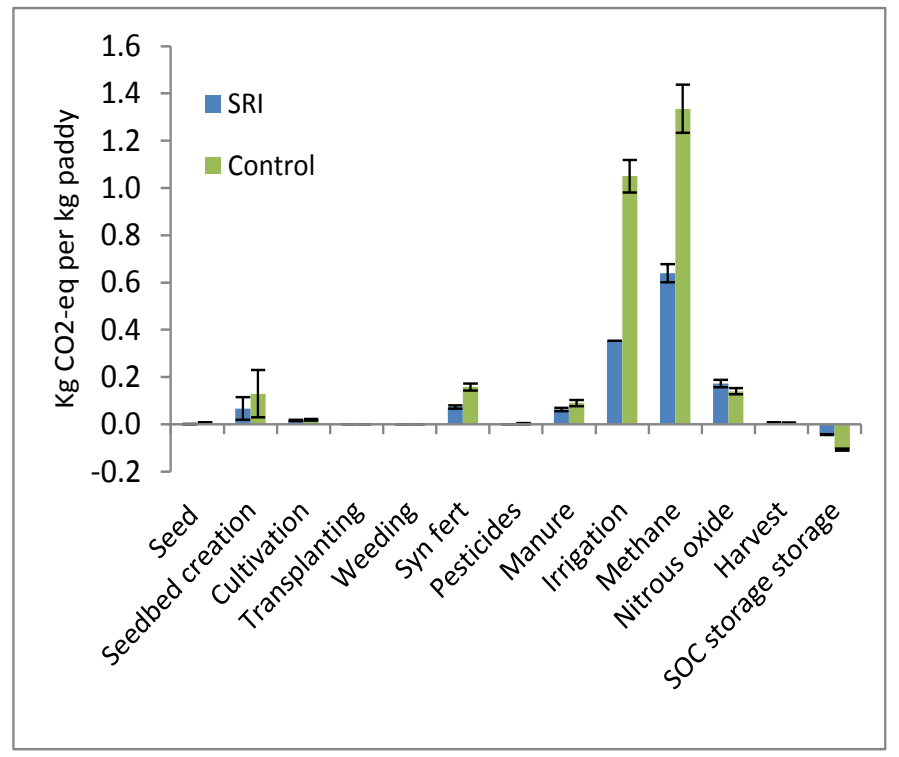

